\title{
Endothelial cell loss in herpes zoster keratouveitis
}

\author{
AHONEN REIJO, VANNAS ANTTI, AND MÄKITIE JUKKA \\ From the Department of Ophthalmology, University of Helsinki, Finland
}

SUMMARY Fourteen patients were followed up with slit-lamp, noncontact, and wide-field specular microscopical examination for anterior segment changes during unilateral attacks of keratouveitis due to varicella zoster virus (VZV). Ten patients had severe keratouveitis. Their affected eyes presented nonreflecting endothelial changes in different phases of the disease. The first nonreflecting changes suggesting virus endothelitis were observed at the onset of keratouveitis. These changes later recurred for several months. When the corneal oedema had subsided, the mean endothelial cell density of the affected eyes was on average $15.3 \%$ lower $(p<0.01)$ than in the healthy fellow eyes. During early uveitis transient high intraocular pressure (IOP) developed in 5 patients. Patients with severe disease and an episode of high IOP had a $20.2 \%$ lower cell count in the diseased than in the healthy fellow eye. During the follow-up interstitial keratitis developed in 2 cases and focal iris atrophy in another 2 . Four patients presented with mild keratouveitis. The posterior cornea and endothelial cell density in this group remained unchanged.

An attack on the ophthalmic division of the trigeminal nerve by varicella zoster virus (VZV) causes herpes zoster ophthalmicus. VZV keratitis is always followed by iridocyclitis. ${ }^{1}$ Complications such as corneal scarring, glaucoma, iris atrophy and anterior segment necrosis occur in half the patients. ${ }^{23}$ Corticosteroids are generally used in the treatment of zoster keratouveitis, but they may prolong the duration of keratouveitis and increase complications. ${ }^{23}$ Recently Sundmacher and Müller ${ }^{4}$ described specular microscopic changes in the endothelium during ophthalmic herpes zoster. Apart from this, posterior corneal reactions during herpes zoster keratouveitis have not been reported, though during herpes simplex keratouveitis endothelial changes including cell loss have been described. ${ }^{5-7}$ Therefore in the present study special attention was paid to the posterior cornea during VZV keratouveitis.

\section{Material and methods}

The patients were 8 women and 6 men with unilateral herpes zoster keratouveitis. Their ages ranged from 56 to 81 (mean 67.9) years. Patients with a history of other ocular diseases were excluded from the study.

Correspondence to Dr R. Ahonen, Department of Ophthalmology, University of Helsinki, Haartmaninkatu 4 C, SF-00290 Helsinki 29, Finland.
The patients were admitted to the University Eye Clinic during early keratouveitis, and an ocular examination was performed. The duration of hospital care varied from 6 days to 3 weeks. Hyoscine $2.5 \mathrm{mg} / \mathrm{ml}$ (Oftan Scopolamin), 1 drop 3 times a day, was routinely used for mydriasis. Topical prednisolone 10 $\mathrm{mg} / \mathrm{ml}$ (Pred Forte), 1 drop 3 or 4 times a day, was added to the treatment in 9 patients when the epithelium was intact. Patients with elevated IOP received topical timolol $2.5 \mathrm{mg} / \mathrm{ml}$ (Blocanol), 1 drop twice daily. After hospital treatment follow-up examinations were performed 4 times on average. The follow-up time ranged from 2 to 29 months.

The central endothelial mosaic was examined and photographed with both noncontact and wide-field specular microscopes during attacks of keratouveitis. Photographs were taken for analysis of endothelial cell density when the uveitis and stromal oedema had subsided. Endothelial cell density in each case was counted with variable frame analysis by using a digitiser (Apple II). Two wide-field photographs were randomly selected and an area enclosing clearly visible cells was outlined in each. The analysed areas per eye ranged from 0.1064 to $0.3587 \mathrm{~mm}^{2}$ (mean $0 \cdot 2089)$ and the number of cells from 255 to 1053 (mean 567). Contralateral healthy eyes served as controls for the endothelial cell density counts. Student's $t$ test was used in the statistical analysis. 
Table 1 Clinical findings and endothelial cell densities

\begin{tabular}{|c|c|c|c|c|c|c|c|c|}
\hline \multirow[t]{2}{*}{$\begin{array}{l}\text { Patient } \\
\text { no. }\end{array}$} & \multirow[t]{2}{*}{$A g e^{*} / \operatorname{Sex}$} & \multirow{2}{*}{$\begin{array}{l}\text { Type of } \\
\text { uveitis }\end{array}$} & \multirow{2}{*}{$\begin{array}{l}\text { Duration of } \\
\text { keratitis } \\
\text { (weeks) }\end{array}$} & \multirow{2}{*}{$\begin{array}{l}\text { Duration of } \\
\text { uveitis } \\
\text { (weeks) }\end{array}$} & \multicolumn{2}{|c|}{ Visual acuity $\ddagger$} & \multicolumn{2}{|c|}{$\begin{array}{l}\text { Endothelial cell density } \\
\left.\text { (cells } / \mathrm{mm}^{2}\right)\end{array}$} \\
\hline & & & & & $\begin{array}{l}\text { Affected } \\
\text { eye }\end{array}$ & $\begin{array}{l}\text { Control } \\
\text { eye }\end{array}$ & $\begin{array}{l}\text { Affected } \\
\text { eye }\end{array}$ & $\begin{array}{l}\text { Control } \\
\text { eye }\end{array}$ \\
\hline 1 & $81 / F$ & $c+f l$ & 4 & 3 & 0.5 & $1 \cdot 0$ & 2708 & 2663 \\
\hline 2 & $72 / \mathrm{M}$ & $c+f$ & 4 & 2 & $0 \cdot 7$ & $1 \cdot 0$ & 2685 & 2950 \\
\hline 3 & $73 / \mathrm{F}$ & $c+f l$ & 8 & 4 & 0.2 & 0.5 & 2688 & 2668 \\
\hline 4 & $65 / \mathrm{M}$ & $c+f$ & 4 & 1 & 0.7 & 0.6 & 2852 & 2810 \\
\hline 5 & $76 / \mathrm{F}$ & $e+t$ & 12 & 4 & $0 \cdot 5$ & $1 \cdot 0$ & 1937 & 2936 \\
\hline 6 & $69 / \mathrm{F}$ & e & 4 & 1 & $1 \cdot 0$ & $1 \cdot 0$ & 2217 & 2489 \\
\hline 7 & $56 / \mathrm{M}$ & $e+t$ & 8 & 3 & 0.6 & $0 \cdot 6$ & 1853 & 2537 \\
\hline 8 & $70 / F$ & $e+f$ & 40 & 8 & $0 \cdot 2$ & $0 \cdot 2$ & 3009 & 3189 \\
\hline 9 & $63 / \mathrm{M}$ & $e+t$ & 6 & 3 & 0.05 & 0.7 & 3262 & 3236 \\
\hline 10 & $70 / \mathrm{F}$ & $\mathrm{e}$ & 4 & 2 & 0.7 & 0.8 & 2398 & 2719 \\
\hline 11 & $61 / \mathrm{M}$ & $\mathrm{e}$ & 4 & 2 & $1 \cdot 0$ & $1 \cdot 0$ & 2259 & 2589 \\
\hline 12 & $71 / \mathrm{F}$ & $e+t+f$ & 116 & 20 & 0.2 & 0.9 & 2082 & 2664 \\
\hline 13 & $56 / \mathrm{M}$ & $\mathrm{e}$ & 8 & 2 & $1 \cdot 0$ & $1 \cdot 0$ & 2654 & 2979 \\
\hline 14 & $68 / F$ & $e+t$ & 52 & 8 & 0.4 & 0.7 & 2341 & 3005 \\
\hline
\end{tabular}

${ }^{*}$ Years. ${ }^{\dagger} \mathrm{c}=$ cells; $\mathrm{e}=$ endothelitis; $\mathrm{f}=$ focal iritis; $\mathrm{fl}=$ flare; $\mathrm{t}=$ trabeculitis. $\neq$ On the last visit with overcorrection.

\section{Results}

The patient data are presented in Table 1. All the patients had a typical rash over the ophthalmic nerve area, including the nasociliary branch. Keratouveitis was observed in every patient. The latent period between the appearance of the rash and keratitis varied from 5 days to 4 weeks. Punctate epithelial keratitis with epithelial oedema was seen in all affected eyes early during the ocular attack. Large epithelial ulcerations developed in 8 patients, one of whom presented with a dendritic form. The latency between epithelial lesions and anterior uveitis varied from 5 to 28 (mean 15) days.

The patients were divided into 2 groups according to the severity of the VZV keratouveitis. A mild form of keratouveitis was seen in 4 patients. This consisted of punctate epithelial keratitis with mild oedema in the anterior stroma and cells and flare in the anterior chamber. The mean duration of the keratitis was 35 days and of the uveitis 18 days. Morphologically the central endothelium of the affected eyes remained unchanged in this group.

A severe form of keratouveitis was seen in 10 patients. The symptoms included ocular irritation and photophobia, with punctate epithelial keratitis, followed by moderate to severe disciform oedema in the stroma, with folds in the Descemet's membrane and inflammatory changes in the anterior chamber. The mean duration of the keratitis was 153 days and of the uveitis 37 days. In an early phase of the uveitis nonreflecting endothelial changes (Fig. 1) suggestive of endothelitis were observed in the severely affected eyes. Endothelial changes were usually seen round the area of keratic precipitates (KPs). Two patients (6 and 13) showed nonreflecting endothelial changes though no KPs developed during uveitis. One patient (14) had central endothelitis without signs of anterior uveitis on the first day in hospital. On the next day cells and flare were seen in the anterior chamber, and the endothelium was coated with cell-like material. Two days later mutton fat KPs were observed on the central endothelium.

Two patients ( 8 and 12$)$ presented 8 and 20 months later with recurrent attacks of ocular pain and irritation, when slight stromal oedema and nonreflecting endothelial changes were observed. During these attacks the anterior chamber remained quiet. The endothelium of the contralateral eye was normal. One patient (12) was seen 10 times during the last 8 months of the follow-up. Slight stromal oedema and nonreflecting endothelial changes with ocular pain and irritation were seen 4 times, and the endothelial mosaic was intact at 6 control visits. The endothelial cell density remained unchanged during these recurrent attacks.

During keratouveitis 8 eyes showed KPs, 4 of which were mutton fat type (patients $7,10,12,14$ ). Most KPs were observed on the central endothelium, which was also the site of intense discoid stromal oedema. Transient elevation of IOP $(34-42 \mathrm{mmHg})$ as a sign of involvement of the trabecular meshwork was measured in 5 patients $(5,7,9,12,14)$. Other signs of trabeculitis in these patients were nonreflecting endothelial changes and KPs in the corneal periphery. Focal oedema of the iris and haemorrhage in the anterior chamber were seen in 2 patients $(8$, 12). This resulted in focal iris atrophy at a later stage.

After keratouveitis, stromal scarring, which was seen with a slit-lamp as several discoid-like and grey 

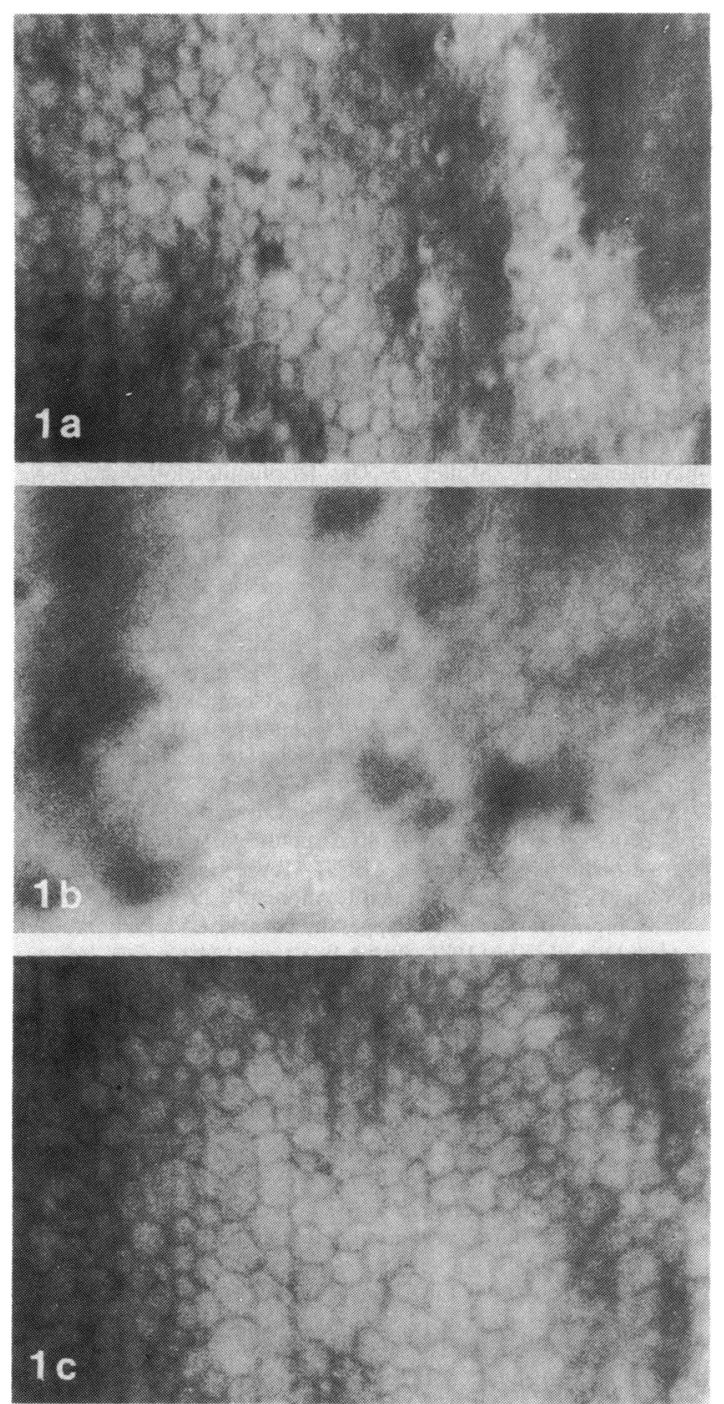

Fig. 1 Specular microscopic pictures demonstrating the central endothelium in different phases of VZV keratouveitis (patient 14) $(\times 152$. a: Nonreflecting changes on the first day of hospitalisation. The anterior chamber was quiet. b: Three days later, when cells and flare were present and mutton fat $K P s$ were observed on the central endothelium.

Nonreflecting changes are larger in size. Corneal oedema blurs the cell boundaires. c: Ten weeks later the anterior chamber is quiet. Nonreflecting changes are no longer seen in the specular reflection.

thickenings of the corneal stroma, was observed in 2 patients ( 9 and 10$)$. Chronic interstitial keratitis with dense scarring of the central and posterior stroma and neovascularisation of the anterior stroma developed in 2 patients (8 and 14) (Fig. 2). In the

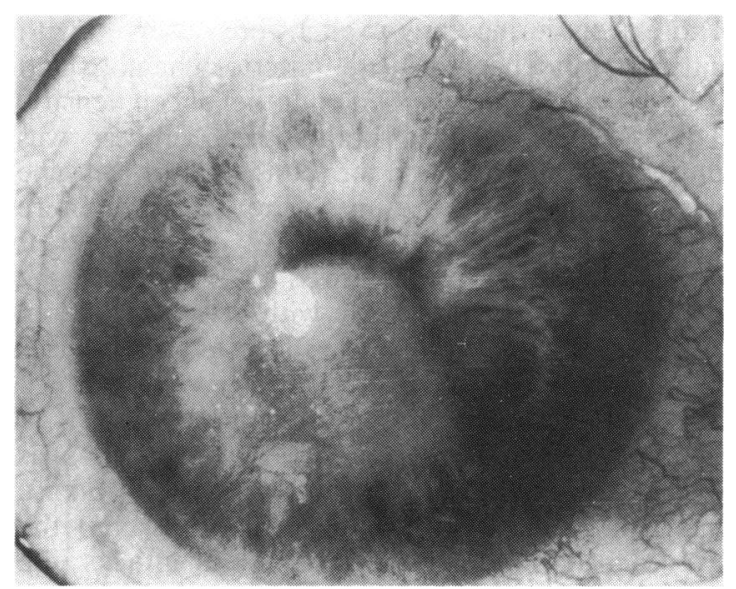

Fig. 2 Patient 815 months after VZV keratitis. The central cornea presents scarring and vascular interstitial keratitis.

patients with mild keratouveitis the mean endothelial cell density of the affected eyes was 2733 cells $/ \mathrm{mm}^{2}$ and in the contralateral eyes 2773 cells $/ \mathrm{mm}^{2}$. The difference between the cell densities was $1.5 \%$. In the patients with severe keratouveitis the endothelial cell density in the affected eyes was 2401 cells $/ \mathrm{mm}^{2}$ and in the healthy fellow eyes 2834 . The difference between the cell densities was $15 \cdot 3 \%(\mathrm{p}<0.01)$. In this group the mean endothelial cell density was $20.2 \%$ lower in the affected eyes with raised IOP and $10.2 \%$ lower in the eyes without pressure increase.

\section{Discussion}

A characteristic finding in ophthalmic herpes zoster was transient nonreflecting endothelial areas during incipient uveitis. This was accompanied by loss of the endothelial cells, especially in eyes with high IOP. It is noteworthy that nonreflecting endothelial changes were also seen in a later stage of the disease. The endothelial cell density remained unchanged during these attacks.

The posterior corneal pathology overlying transient nonreflecting endothelial changes is not fully understood. These changes have been reported earlier in anterior uveitis, in herpes simplex virus keratouveitis, after contact lens insertion, and following corneal trauma. ${ }^{6-13}$ There are probably several histopathological changes at the level of the endothelial cells or Descemet's membrane which can cause such an endothelial cell oedema or inflammatory cell invasion between the endothelium and Descemet's membrane. ${ }^{91114}$

In the present study transient endothelial changes were observed in different phases of the disease. 
Those seen during early uveitis were observed with inflammatory changes in the anterior chamber and were followed by decreased endothelial cell density. This suggested that a pathological process was present at the level of the endothelium. In one patient nonreflecting changes were detected before the appearance of cells and flare in the anterior chamber, which were followed by coating of the posterior endothelial surface with cell-like material and KPs. This particular case suggested direct virus invasion into endothelial cells followed by an attack of immunocompetent cells against endothelium.

The recurrent nonreflecting endothelial changes were observed in 2 patients complaining of intense pain and ocular irritation several months after the uveitis had subsided. During those attacks the anterior chamber was quiet and the endothelial cell density remained unchanged. This suggested that there was a pathological process on the level of Descemet's membrane and posterior stroma in agreement with our own unpublished electron microscopic studies and the studies of Hedges and Albert. ${ }^{15}$ The endothelial cell count was $10 \cdot 2 \%$ lower in the eyes with endothelitis without elevated IOP and $20.2 \%$ lower in the eyes with inflammatory pressure attacks. Whether virus cytolysis or an attack of immunocompetent cells is more harmful to endothelial cells is not yet clear. Acute uveitis itself does not seem to affect the endothelial cell density. ${ }^{16}$

Acute attacks of angle-closure glaucoma are known to cause loss of endothelial cells. ${ }^{17}{ }^{18}$ In the Posner-Schlossman syndrome, too, a $12 \%$ decrease in endothelial cell count has been found. ${ }^{19}$ Clinically VZV keratouveitis with elevated IOP has some similarities with the Posner-Schlossman syndrome. Therefore the high decrease in endothelial cell density in the eyes with inflammatory pressure attacks could partly be due to elevated IOP. The present study confirms that VZV keratouveitis may be a long-lasting disease which, with its complications, threatens the visual integrity. Some of the complications, however, may be prevented by acyclovir therapy. ${ }^{20}$ Early detection and therapy of high IOP should also prevent endothelial cell loss. It is probable that the spreading of living virus into the posterior cornea and the anterior chamber is the initiator of severe keratouveitis. Means to prevent viral invasion are under investigation.

\section{References}

1 Thygeson P, Ostler HB. Zoster and herpes simplex virus uveitis: a comparison. In: Silverstein AM, O'Connor GR, eds. Immunology and immunopathology of the eye. New York: Masson, 1979: 230-40.

2 Ostler HB, Thygeson P. The ocular manifestations of herpes zoster, varicella infectious mononucleosis and cytomegalovirus disease. Surv Ophthalmol 1976; 21: 148-59.

3 Chu W, Pavan-Langston D. Ocular surface manifestations of the major viruses. Int Ophthalmol Clin 1979; 19: 135-67.

4 Sundmacher R, Muller O. Das Hornhautendothel bei zoster ophthalmicus. Klin Monatsbl Augenheilkd 1982; 180: 271-4.

5 Sundmacher R. A clinico-virologic classification of herpetic anterior segment diseases with special reference to intraocular herpes. In: Sundmacher R, ed. Herpetische Angankrangungen. Munchen: Bergmann, 1981: 203-10.

6 Vannas A, Ahonen R. Herpetic endothelial keratitis: a case report. Acta Ophthalmol (Kbh) 1981; 59: 296-301.

7 Vannas A. Ahonen R, Makitie J. Corneal endothelium in herpetic keratouveitis. Arch Ophthalmol 1983; 101: 913-5.

8 Vogt A. Lehrbuch und Atlas der Spaltenlampen mikroskopie des lebenden Auges. Berlin: Springer, 1930; 1: 201-38.

9 Vannas A, Holden B, Makitie J, Ruusuvaara P, O'Donnell JJ. Specular microscopy and ultrastructure of endothelial blebs. Invest Ophthalmol Visual Sci 1979; ARVO suppl: 143.

10 Vannas A, Makitie J, Sulonen J, Ahonen R, Jarvinen E. Contact lens induced transient changes in corneal endothelium. Acta Ophthalmol (Kbh) 1981; 59: 52-9.

11 Krachmer JH, Schnitzer JI, Fratkin J. Cornea pseudoguttata. A clinical and histopathologic description of endothelial cell edema. Arch Ophthalmol 1981; 99: 1377-81.

12 Olsen T. Transient changes in specular appearance of the corneal endothelium and in corneal thickness during anterior uveitis. Acta Ophthalmol (Kbh) 1981; 59: 100-9.

13 Zantos SG, Holden BA. Guttate endothelial changes with anterior eye inflammation. Br J Ophthalmol 1981; 65: 101-3.

14 Inomata H, Smelser G. Fine structural alterations of corneal endothelium during experimental uveitis. Invest Ophthalmol Visual Sci 1970; 9: 272-85.

15 Hedges TR, Albert OM. The progression of the ocular abnormalities of herpes zoster: histopathologic observations of nine cases. Ophthalmology 1981;88 (suppl): 41.

16 Setälä K. Corneal endothelial cell density in iridocyclitis. Acta Ophthalmol (Kbh) 1979; 57: 277-86.

17 Setälä K. Corneal endothelial cell density after an attack of acute glaucoma. Acta Ophthalmol (Kbh) 1979; 57: 1004-13.

18 Olsen T. Endothelial cell damage in acute glaucoma. On the corneal thickness response to intraocular pressure. Acta Ophthalmol (Kbh) 1980; 58: 257-69.

19 Setälä K, Vannas A. Endothelial cells in the glaucomatocyclitis crisis. Adv Ophthalmol 1978; 36: 218-24.

20 McGill J. Herpes zoster acyclovir therapy. Ophthalmology 1982; 89 (suppl): 99. 